\begin{tabular}{c} 
Volume and Issues Obtainable at Center for Sustainability Research and Consultancy \\
Sustainable Business and Society in Emerging Economies \\
ISSN: 2708-2504 ISSN (E) 2708-2172 \\
Volume 1: No. 1, June 2019 \\
CSRᄃ \\
Journal homepage: www.publishing.globalcsrc.org/sbsee \\
\hline
\end{tabular}

\title{
Attitude towards Green Consumption among College and University Students in Bahawalpur Pakistan
}

\author{
${ }^{1}$ Asma Fazal
}

${ }^{1}$ The Islamia University of Bahawalpur Pakistan asmafazal397@gmail.com

\begin{tabular}{l} 
ARTICLE DETAILS \\
\hline History \\
Revised format: May 2019 \\
Available Online: June 2019 \\
\hline Keywords \\
Green Consumption, \\
Sustainability, Attitude, Green \\
Purchase Intention (GPI), \\
Green Purchase Behavior \\
(GPB)
\end{tabular}

\section{JEL Classification: \\ E21, Q56, C91, C99}

\begin{abstract}
Green consumption is using goods and services to fulfill needs, adopting a better lifestyle while decreasing the consumption of natural assets, unhealthy material and outflow of waste and impurities in daily lives to save the environment for future generations. The main objective was to identify the impact of Green Attitude on green purchase intention and green purchase behavior along with sub variables. The study was conducted in the area of South Punjab, Pakistan in which the students were taken as consumers to find out if the consumer attitude has any impact on green purchase intention and green purchase behavior. The population of the study was students enrolled in colleges and universities of South Punjab Pakistan which includes the levels of study intermediate, graduation, masters, MPhil and $\mathrm{PhD}$ with the sample of 250. SPSS software was used to interpret the collecting data to draw results. This study has limited data, limited time, limited and limited sources, limited population, due to which results of this study may not be generalizable to other population or place. The conclusion of the study was that there is a positive impact of Attitude on Green Purchase Intention and Green Purchase Intention and there is positive and slightly strong relationship between the independent and dependent variables.
\end{abstract}

(c) 2019 The authors, under a Creative Commons AttributionNonCommercial 4.0

Corresponding author's email address: asmafaza1397@ gmail.com

Recommended citation: Fazal, A., (2019). Attitude towards Green Consumption among College and University Students in Bahawalpur Pakistan. Sustainable Business and Society in Emerging Economies, 1(1), 15-28

DOI: $10.26710 /$ sbsee.v1i1.1004

\section{Introduction}

The business landscape has changed drastically in the past years. Credit goes to the rise of capitalism many people attribute their self-worth with money and how much stuff they can buy with said money. The more people buy, the more they consume. Consumption of these services and goods is massive which feeds the constant cycle of demand and supply. Not all the products we use are environmentally or socially friendly, for example, cigarettes which are detrimental to both, the human health and your surroundings. 
This is where the practice of sustainable consumption comes in. What is sustainable consumption? It is the procedure of consuming green services and products which have minimal impact on the environment, beneficial for human health, and do not destroy the natural ecosystem. By observing early literature we can say those who are interested in preserving the environment will apparently purchase the products which are not unsafe for the environment. This can be referred to as green consumption (Sreen, Purbey, \& Sadarangani, 2018). Consumers can cause an increase and decrease in the demand and supply of products in the market.

According to Fien, et al.(2008) humans have used more natural material than in the past fifty years which is the most used in human history ever which is clearly unsustainable. That is why consumption is decisive in our survival (Fien et al., 2008). According to postmodern theories, consumption determines the lifestyle and culture. Different measures of consumption make consumers form new groups. For example, an environmentally conscious consumer does not act similar to a non-conscious one (Haanpää, 2007).

First book about green consumption "The Green Consumer Guide" was issued in the U.K in 1980 to answer the question of modern mechanized society, "shopping has become a leisure activity in itself". Around 700 companies started the league 'Buy Green' in Japan. Companies and government in Japan configure Green Purchasing Network (GNP) (Patil \& Patil, n.d.).

Sustainable consumption belongs to youth culture for historical causes. Young people and consumers had a key role in establishment of green consumerism in the international and national settings. For example, serious choices considered as 'green lifestyles' emerged as youth social behavior movements (Autio \& Heinonen, 2004). According to a researcher, Ward (1974, p. 2) issued a paper in which he presented that there are issues that are necessary to get the knowledge about consumer socialization performances. These issues are: (1) how kids develop consumer skills, knowledge and attitudes, (2) on which these socialization processes contain and (3) how initial learning forms later thinking and opinion regarding green consumption (Promotosh, 2011).

Afridi Jan (2010) stated that in Pakistan the chances of our ecosystem getting damaged are increasing which is carrying over 160 million people, and our lack of resources on account of climate change has made the issue of green consumption more difficult. Before the Earth Summit in 1992 Pakistan was among the first few countries to prepare National Conservation Strategy (NCS) in the world. We also brought out early, among other countries, our National Environment Policy, National Energy Conservation, the policy National Sanitation and policy related to drinking clean water ("884Pakistan.pdf," n.d.).

Examining why green values do not affect the people while making purchase decisions when it comes to actual purchasing a product is needed to understand and create a difference in consumer buying actions towards sustainable consumption.

\section{Problem Statement}

Day by day increasing amounts of pollution and the damages made by traditional production methods have made it necessary to be environmentally conscious (Shaikh, 2019). The solid waste rate in Pakistan is 48 tons per year generated from metropolitan areas, which is rising by $2 \%$ annually. In Pakistan waste is produced more than the resources to cope with it. In Punjab, only in Lahore is there a proper waste management system which has been outsourced from Turkish companies (Iqbal, 2019).

We want to examine the consumer's attitude regarding the consumption of harmless (to environment) products and what are other factors affecting the attitudes of people and what impact it can cause on purchasing intention and purchasing behavior when it comes to sustainability. Consequences of the 
solution of this problem will make us aware of the attitudes of people towards green consumption what affects their green purchasing intentions and behaviors so we can make future preparations accordingly.

The current problem is the difference between the green buying intentions and green buying behaviors. Despite the willingness to preserve the environment people do not end up buying green products if they are pricey than non green products.

\section{Research Gaps}

There are two gaps in the study, theoretical gap and contextual gap, the theoretical gap in the literature is the attitude behavior gap by combining the Theory of Planned Behavior (TPB) and Pro-environmental Planned Behavior (PEPB) Model along with more variables like Long Term Orientation Collectivism and Man Nature Orientation with moderating role of Gender. We are using these 2 models to find out about consumers' attitude towards green consumption and its influence on purchasing intentions and purchasing behaviors of green buyers.

We conducted this research in the area of South Punjab, Pakistan. Before this, in South Punjab, there is no research conducted in this area related to examining consumer attitude towards green consumption which depicts consumers' green purchase intention and green purchase behavior. This study tends to fill this gap by finding out the collective perception of young consumers' who are currently studying in colleges and universities about green consumption.

\section{Research Objectives}

- To investigate consumers' Attitude towards Green Consumption.

- To investigate the impact of consumers' attitude towards green purchase intention.

- To investigate the impact of consumers' attitude towards green purchase behavior.

- To investigate the association between green purchase intention and green purchase behavior.

\section{Literature Review}

\subsection{Attitude towards Green Consumption}

Generally speaking, environmental activists believe that by buying environmental friendly products or that their packaging can be recycled, products that can be properly disposed of with non-biodegradable garbage, consumers can come up with the contribution to their environment slightly and significantly to make this world a better place (Abdul-Muhmin, 2007). Arli et al. (2018) represented the findings of Hansla et al. (2008) in his study that consumers' are more ready to pay for green electricity with a massive demand. Similarly, he unfolded the same findings regarding Barber et al. (2010) for environmentally-friendly wines, and stated about green-hotel, many studies illustrated that intention of buying green products is positively influenced by attitude(Arli, Tan, Tjiptono, \& Yang, 2018). A study was conducted to check household attitudes and judgment about recycling old products and discussed problems of recycling goods can turn responses into high material recycling levels. Results specified that households recycle in the first place to protect their surroundings but do not continue if there is inconvenience or time constraint. This was the largest barrier to recycling according to this study (Ramayah, Lee, \& Mohamad, 2010).

\subsection{Green Purchase Intention}

By studying the previous studies of green consumer intention, researchers aim is to understand the motivation behind purchasing environmentally friendly goods (Y. C. Huang, Yang, \& Wang, 2014). In previous marketing related studies purchasing intention has been a significant notion to estimate the modification of new products and services and also repetition of old existing products, most marketers use consumers purchase intention to predict their demands. Prior studies have illustrated that, consumers who have intention to buy tend to display greater actual buying rates as compared to the customers who do not intend to buy at all (Brown, Pope, \& Voges, 2003). Rizwan et al. (2017) stated in his study that the human beings with the attribute of external locus of control the entire time, assume that external conditions and 
reasons for their failures (poor fortune, no job are because of bad monetary situations and God's force). Therefore, in his study he anticipated that individuals with the trait of external locus of control have not as much control over ecological affairs, and relatively, have lesser ecological buying intentions (Am M A D Ri Z Wa N, Mm A D Ha Ssa N, Wa N Qa I Ser Dan I Sh, \& Ri, 2017).

\subsection{Green Purchase Behavior}

The correlation of green attitudes and similar behavior keeps changing, and depends on study of interest (Moser, 2015). The society and public are now more conscious and taking notice about environmental pollution which is caused by manufacturing and corresponding industries activities (Rizwan et al., 2013).

In literature, while searching for different indicators of buying green, many studies were carried out in developing countries like India, Taiwan, Malaysia, Brazil, Indonesia, and China. In the developed countries, most studies observed the highest rate of green purchases in the US (Liobikiene, Mandravickaite, \& Bernatoniene, 2016). Cornelissen et al. (2008) stated, according to Straughan, R. D. and Roberts, J. A. (1999) an individual with favorable environmental behavior will possibly buy more sustainability supported products and services even on high rates more often, as this positivity indicates that a person's actions towards environment will enhance the chances that he will go for ecological products more frequently (Cornelissen, Pandelaere, Warlop, \& Dewitte, 2008).

\subsection{Environmental Attitude and Green Purchase Intention}

Behavioral intentions indicate a person's personalized possibility of being involved in activities, which can get affected by the point of views about getting involved in that specific behavior (Nam, Dong, \& Lee, 2017). Paul et al. (2016) further depicted that attitude has a straight and implicit capability to affect ecological concern and green behavioral intention, concluded that attitude plays a significant role which can mediate among the intentions of green purchasing and other variables (Paul et al., 2016).

Researchers like Paul (2016) also showed that there is constructive linkage between attitude regarding green products and green purchase intentions. Most of the studies reported that attitudes have an encouraging influence on green consumption and green buying intention.

$H$ (1): For sustainable consumption, attitude has positive impact on the green purchase intention

\subsection{Green Purchase Intention and Green Purchase Behavior}

Yadav et al. (2017) in his experiment showed supported that the association between purchasing behavioral intentions and green buying behavior is quite positive (Yadav \& Pathak, 2017). Chaudhry \& Bisai stated that Green purchase behavior was said to be related positively with green purchase intention in studies from different areas across the globe in many areas of green goods and services just like unrefined food products, green lodging, beverages and tourism (Chaudhary \& Bisai, 2018). Harun et al. (2012) stated that Chan and Lau (2000) designed a conceptual model which was about man nature orientation, green purchase intention, environmental concern and environmental knowledge. The result of the study was that real buying behavior was extremely relied on one person's green purchase intention and the representation was supported by TRA theory and TPB theory discovered by Azjen and Fishbein (1980; 1991) (Aman, Harun, Hussein, \& Author, 2012).

H (2): For sustainable consumption, green purchase intention has a positive impact on green purchase behavior.

\subsection{Subjective Norms}

Defranc et al., (2008) stated that according to Ajzen (1991) Subjective Norm is considered to be a societal aspect in nature (Defranc et al., 2008). Subjective norms cite that what an individual thinks how other people perceive them (those who are related or known to the individual) would like them to indulge in a specific behavior in a given situation. So, according to subjective norms we can say that people behave with the opinion of significant others (Yadav \& Pathak, 2017). Subjective norms disclose the level to 
which a person thinks morally accountable for others by purchasing green products and how significant the positive social image is for them (Barber, Bishop, \& Gruen, 2014).

\subsection{Subjective Norms and Green Purchase Intention}

Previous literature has argued that subjective Norms are the main indicator of Purchase Intention (Sreen et al., 2018). According to Mufidah et al. (2018) the consumers were expected to get influenced by social groups through social pressure, and prefer eco-label products. If the society supports people to use green products then consumers will consume more green products. It was proved that Subjective norms have a positive impact on buying intention which checks the environment total impact and assess their participation and green purchasing behavior (Mufidah et al., 2018). In some cases, the consideration of subjective norms has not proven to be sufficient to forecast the behavior of human beings (Tommasetti, Singer, Troisi, \& Maione, 2018).

H (3): For sustainable consumption, subjective norms have a positive impact on the green purchase intention.

\subsection{Perceived Behavior Control}

Kumar, (2012) presented that Jager (2000) narrated that consumer purchasing decision contains many different and connected parts and at time many circumstanced factors among which perceived behavioral control is one, it helps attitude to make a decision (Kumar, 2012). As mentioned in the TPB theory, PBC is related to the results of a person's previous first hand experiences and problems occurred during the experience that decides the level of the person's perception concerning how simple or hard is to carry out a behavior (Vantamay, 2018). It revolve perception concerning approach to what resources and how many chances are required to perform the behavior, which includes more finances, time, and other facilities, and individuals' own self confidence in his capability to conduct the behavior (Gangwal \& Bansal, 2016).

\subsection{Perceived Behavior Control and Green Purchase Intention}

PBC is not only a strong factor that influences attitude to change behavior, but it is also silently believed that it is regarded as a significant resource for decision making (Ajzen \& Madden, 1986). The more power and opportunities people think they control, and very less barriers or disadvantages they assume, the greater should be their perceived power over the behavior (Ajzen \& Madden, 1986). Nam et al. (2017) narrated that Roberts (1996) also described that purchase intention and attitude can also get positively influenced by perceived behavior control (Nam et al., 2017). Degree of difficulty and ease depends on accessibility to a product, in which place to locate it and how they will obtain that product for consumption. If an environmentally friendly product is not available it may constitute a restriction for a highly motivated consumer (Kumar, 2012).

H (4): For sustainable consumption, perceived behavior control has a positive impact on the green purchase intention.

\subsection{Perceived Environmental Concern}

Aman et al. (2012) portrayed that Masud et al. (2003) elaborated that environmental concern is a belief, an attitude and the level of concern a person has for the environment (Aman et al., 2012). Pollard et al. (1999) further depicted environmental concern as the awareness and realization of consumers to the fact that the environment is in risk and inherent assets are restricted in size (Pollard et al., 1999). Another researcher depicted that according to Maloney et al. (1975) environmental concern is related to how much an individual is emotional about his environmental problems (Chan, Chan, \& Lau, 2017).

\subsection{Relationship with Attitude, Subjective Norms and Perceived Behavior Control}

Bamberg (2003) argued about the environmental concern that it does not have that much influence on green perceived behavior control (Bamberg Sebastian, 2003). While Aman et al. (2012) presented that environmental concern plays a very important role when it comes to influence the consumer's ecological buying intention. Attitudes tend to mediate the relationship between green purchase intention and environmental concern (Aman et al., 2012). Another study presented that green concerns indirectly 
influence specific behavior through when they create an effect on the generation and the way they evaluate the situation-specific norms in relation to the decision how they get information about these green products and the suppliers of these products (Cherian \& Jacob, 2012).

$\mathrm{H}$ (5): For sustainable consumption, perceived environmental concern has a positive impact on attitude.

$H$ (6): For sustainable consumption, perceived environmental concern has a positive impact on subjective norms.

H (7): For sustainable consumption, perceived environmental concern has a positive impact on perceived behavior control.

\subsection{Perceived Authority Support}

Perceived authority support is what a person thinks about how much support an authorized party or agency can provide them when it comes to conducting a behavior by an individual to social problems. The authority can be held by the government, any institute or any organization (Mufidah et al., 2018). The eco-label program conducted by the government is expected to create an impact on the consumer's priority towards the eco label products. If the government conducts these programs efficiently, people will be more motivated to purchase the eco-label products (Tommasetti et al., 2018).

\subsection{Relationship with Attitude, Subjective Norms and Perceived Behavior Control}

A study carried out in Indonesia, proved that PAS tend to have a positive impact on Subjective Norms, Attitude, PBC, and PEC for environmental impact assessment participation (Lin, Nadlifatin, Amna, Persada, \& Razif, 2017). Another study held in Taiwan also proposed that the perceived authority support positively influences attitude, subjective norms, and perceived behavior control in the eco-label product usage (Mufidah et al., 2018).

H (8): For sustainable consumption, perceived authority support has a positive impact on attitude.

H (9): For sustainable consumption, perceived authority support has a positive impact on subjective norms.

H (10): For sustainable consumption, perceived authority support has a positive impact on perceived behavior control.

\subsection{Collectivism}

Collectivism is a person's quality in which an individual prioritizes others' benefits and advantages rather than his own personal benefits and makes an action which is harmful to the climate (McCarty \& Shrum, 2003). Specifically, collectivistic people tend to care more about recycling unlike individualistic because they prefer more to work in collaboration, care more for their people, and publicly they are in the favor group instead of personal opinions and values and these people are pillars of the group (Tommasetti et al., 2018).

\subsection{Relationship with Attitude, Subjective Norms and Perceived Behavior Control}

According to Rizwan et al. (2017), Kim (2005) found a positive power of collectivism on consumers' standards of behaviors about their recycling behavior Therefore, it can be said that the collectivists may show high tendency towards buying green products (Am M A D Ri Z Wa N et al., 2017). Based on the theories related to value, attitude and behavior hierarchy, two researchers Homer \& Kahle have explained the remarkable influence of a man's basic beliefs of collectivism on how their recycling behavior is, with the help of attitude as mediating variable toward recycling (Chan et al., 2017). As stated by Aswal (2017). Handique, (2014), on the other hand, suggests people with collectivist nature tend to keep traditional ideas, stay inflexible in modifying their behaviors and intentions, which therefore shows that collectivism can also negatively influence the green purchase intention (Aswal, 2017). Another study found that a collectivistic person's basic beliefs are positively related with sustainable environmental purchase behavior (Tommasetti et al., 2018).

$\mathrm{H}$ (11): For sustainable consumption, collectivism has a positive impact on attitude.

$\mathrm{H}$ (12): For sustainable consumption, collectivism has a positive impact on subjective norms.

H (13): For sustainable consumption, collectivism has a positive impact on perceived behavior control. 


\subsection{Man Nature Orientation}

Man-nature orientation is elaborated as a capability of people to survive in consonance with the natural environment (Kluckhohn \& Strodtbeck, 1961). Man-nature orientation can be described as connection that a man shares with his environment. Man nature orientation level is low in the societies who think they can conquer nature, while, the societies in which man nature orientation level is high, have a direct relation with attitude regarding ecological consumption and they live more healthy lives than those who have low level (Sreen et al., 2018).

\subsection{Relationship with Attitude, Subjective Norms and Perceived Behavior Control}

Wijaya (2009) in India found out that there is a direct relation between Attitude and Man-Nature Orientation and attitude. Most people in India bow before various kinds of nature like trees, different rocks and animals so, one may conclude that man nature orientation is high there and expected to live in a sound environment (Wijaya, 2017). Man-Nature Orientation is directly associated with the Attitude regarding green consumption while on green purchase intention it creates an indirect impact (Sreen et al., 2018). There is no or less literature in Pakistan related to analyzing the correlation of man-nature orientation and green purchase intention. Also, in the universal circumstance there are very few experiments in the literature that describe the rapport of man nature orientation with green purchase intention, green purchase behavior and attitude.

$\mathrm{H}$ (14): For sustainable consumption, man nature orientation has a positive impact on attitude.

$\mathrm{H}$ (15): For sustainable consumption, man nature orientation has a positive impact on subjective norms.

$\mathrm{H}$ (16): For sustainable consumption, man nature orientation has a positive impact on perceived behavior control.

\subsection{Long Term Orientation}

Long-term orientation is related to how a person perceives that where a society will stand while in a position while fighting with its current long term problems in the future (Leonidou, Leonidou, \& Kvasova, 2010). Long term orientation is the encouraging development of intrinsic worth placed to get potential benefits, in particular, protection, carefully using the resources and non materialism (Sharma, 2010).

\subsection{Relationship with Attitude, Subjective Norms and Perceived Behavior Control}

Research by Leonidou et al. (2010) proved that people who have long-term oriented nature tend to be more optimistic about sustainable consumption and have a positive attitude because these products will proved benefits in the future (Leonidou et al., 2010). Other previous researches have shown the same that if a person is long term oriented by nature he/she will have a positive attitude towards sustainable ecological products (Sreen et al., 2018). According to Nguyen (2017), some pragmatic studies have verified that consumers with long term orientation identify the high environmental impact of cars when it comes to environmental protection and that they generally show a great concern and attitude toward the environmental protection (Nguyen, Lobo, \& Greenland, 2017).

H (17): For sustainable consumption, long term orientation has a positive impact on attitude.

$\mathrm{H}$ (18): For sustainable consumption, long term orientation has a positive impact on subjective norms.

H (19): For sustainable consumption, long term orientation has a positive impact on perceived behavior control.

\subsection{Green Consumption in Pakistan}

Like other developing countries, Pakistan is also in its early period of development. That is why to perceive the relationship between attitude regarding green purchase and green buying intention, and to find out the factors through which we can meet the space between green purchase intention and green buying behavior, there is still need of moderating and mediating variables which may present the different angles of attitude (Ali, 2016). A researcher brought out the result of his research that Green purchasing intention of consumers in Islamabad people are concerned about environmental problems and they do not only support the idea of sustainable consumption but also go for ecological products when they have to do 
actual purchasing of products which means people who have intention of purchasing these products they will buy even if they have to pay premium as compared to the people who have little concern (Ali, Khan, Ahmed, \& Shahzad, 2011). Rizwan et al. (2013) carried out the result of their study which was aimed to study what is the sustainability practices carried out by the owners of hotels in Pakistan. The result suggested that most of the sample hotels using sustainability as a business strategy and a proper systematic application in sustainability is missing and all their efforts are on growing the goodwill of the company by promising to reduce environmental problems through marketing campaigns and increasing commercial performance whereas, very few of them were executed that too only when needed (Rizwan et al., 2013). Another research was conducted in some departments of Punjab University of Lahore, to examine the relationship between green purchase intentions of consumers and man nature orientation, environmental concern, social image and self image. The researchers concluded that there is no direct link among environmental concern and green purchase intention and neither does it have any positive or negative impact on it (Zia-ur-Rehman \& Dost, 2013).

\section{Conceptual Framework}

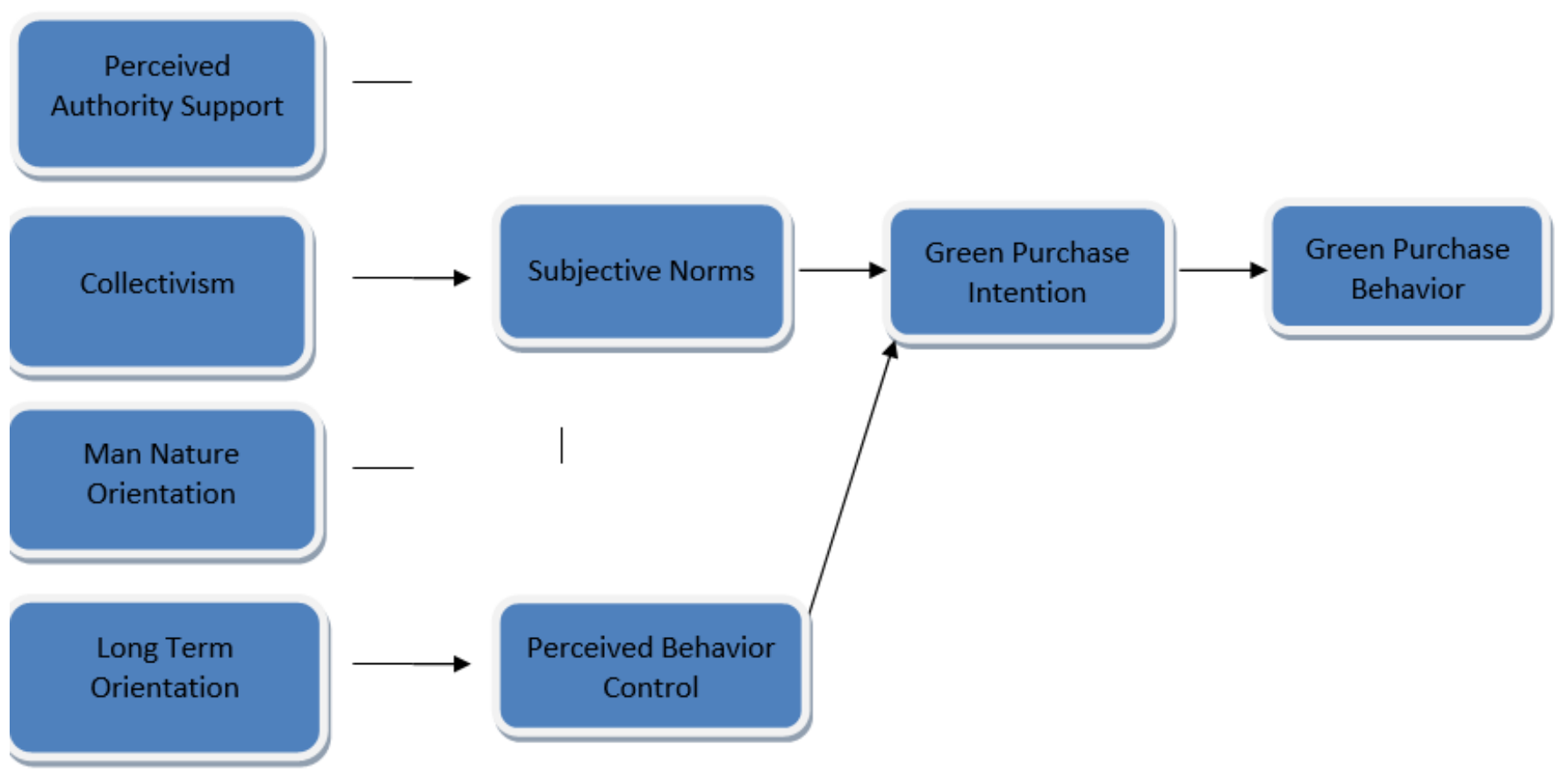

Fig. 1 Proposed Research Framework

\section{Methodology}

\subsection{Research Design}

Researchers believe that for investigating the social behaviors, quantitative research design is mostly used and appropriate (Memar \& Ahmed, 2012). In this study, the research design we used is explanatory in nature because it investigates the problem after identification related to green consumption and it gives the cause to the relationship of independent and dependent variables. Explanatory study is quantitative in nature (checking the nature of objective theories by thoroughly investigating what impact a variable causes to another variable). In order to be able to analyze all the hypotheses and conclude what factors affect the green buying behavior to answer the research questions which are considered to be social behavior, and the research method being used is quantitative in nature.

A deductive approach has been used throughout the research in which theories were developed first and made some tentative assumptions in the form of hypothesis, collected and analyzed data and accepted or rejected hypothesis based on that statistical and empirical analysis. Then, the study has shown solid developed theory. Statistical approach has also been used to dig out the correlation between variables by SPSS software. 


\subsection{Survey Instrument}

The questionnaire used for this study was adapted and a survey method has been applied to collect data in which closed ended questions were asked from the concerned population. In questionnaire a five point Likert scale was used which includes 1 for strongly Disagree to 5 for strongly Agree. The questionnaires got filled by meeting respondents in person.

The questionnaire is divided into three sections. The opening portion of the questionnaire gives some basic insights of the topic like what it is. The next part gathers demographic information about the respondent such as, gender, age and nature of their institution. In the third section, different questions related to the variables and the different dimensions of those variables have been asked.

\subsection{Population and sample size}

The sample size of the study should be satisfactory so that we can use it to conclude prudent results out of it. The population of this research is the young students between the age of 16 and 38 years old studying in universities and colleges of South Punjab, Pakistan. As there are many colleges and universities in South Punjab so the unit of analysis we chose students from particular colleges and universities as a sample for our study. The size selected as a sample of our research is 250 and questionnaires were distributed among young students regardless of their gender.

\subsection{Sampling Technique}

Sampling technique plays an important role in collecting adequate data for the research. In this study Simple Random Sampling technique has been (probability method of sampling) adopted to get data from population. This means each one in the population has the equal chance of being chosen as a sample. The advantage of random sampling includes, it requires less expertise to choose a respondent. The following table shows the details of demographic details of respondent taken for the study.

Table No. 1

\begin{tabular}{|l|l|l|}
\hline Metrics & Frequency $(\mathrm{N}=250)$ & Percent $(\%)$ \\
\hline Gender & & \\
Male & 121 & 48.4 \\
Female & 129 & 51.6 \\
\hline Age & & \\
$16-22$ & 88 & 35.2 \\
$23-28$ & 118 & 47.2 \\
$29-32$ & 30 & 12.0 \\
$33-38$ & 14 & 5.6 \\
\hline Education Level & & \\
Intermediate & 36 & 14.4 \\
Graduation & 65 & 26.0 \\
Masters & 61 & 24.4 \\
MPhil & 65 & 26.0 \\
PhD & 23 & 9.2 \\
\hline Institution & & \\
Government & 140 & 56.0 \\
Semi-government & 23 & 9.2 \\
Private & 86 & 34.4 \\
\hline Marital status & & 22 \\
Married & 55 & 78 \\
Unmarried & 195 & \\
\hline
\end{tabular}




\section{Result and Data Analysis}

\subsection{Correlation analysis}

\section{Table No. 2:}

\begin{tabular}{|c|c|c|c|c|}
\hline \multicolumn{5}{|c|}{ Correlations } \\
\hline & & A_avg & $\begin{array}{l}\text { GPI_av } \\
\mathrm{g}\end{array}$ & $\begin{array}{l}\text { GPB_av } \\
\mathrm{g}\end{array}$ \\
\hline \multirow[t]{3}{*}{ A_avg } & $\begin{array}{l}\text { Pearson } \\
\text { Correlation }\end{array}$ & 1 & $.747 * *$ & $.665 * *$ \\
\hline & Sig. (2-tailed) & & .000 & .000 \\
\hline & $\mathrm{N}$ & 248 & 247 & 246 \\
\hline \multirow[t]{3}{*}{$\begin{array}{l}\text { GPI_av } \\
\mathrm{g}\end{array}$} & $\begin{array}{l}\text { Pearson } \\
\text { Correlation }\end{array}$ & $.747 * *$ & 1 & $.714 * *$ \\
\hline & Sig. (2-tailed) & .000 & & .000 \\
\hline & $\mathrm{N}$ & 247 & 249 & 247 \\
\hline \multirow[t]{3}{*}{$\begin{array}{l}\text { GPB_av } \\
\mathrm{g}\end{array}$} & $\begin{array}{l}\text { Pearson } \\
\text { Correlation }\end{array}$ & $.665 * *$ & $.714 * *$ & 1 \\
\hline & Sig. (2-tailed) & .000 & .000 & \\
\hline & $\mathrm{N}$ & 246 & 247 & 248 \\
\hline
\end{tabular}

In statistics, this evaluation method is a tool to calculate the strength of relationship between independent and dependent variables. This is used when the analyst wants to estimate if there is a possibility of correlation between two or more variables. As shown in the table the Pearson values of variables are 0.747 and 0.665 which signifies that the relationship between the main dependent and independent variables is positive and the strength of the relationship is average. Similarly, the relationship among other sub variables is also positive and moderately strong.

\subsection{Regression Analysis}

Regression analysis is used to observe the impact of independent variables on dependent variables. This test also tells how much changes one variable brings to another variable. To measure the influence of multiple factors all at one time multiple linear regression analysis is used by most researchers. In our study we will also be using this technique in SPSS software.

According to the result of regression analysis, hypothesis H1 "green purchase intention has positive impact on green purchase behavior" is accepted. Similarly, here the hypothesis H2: "Attitude has positive impact on GPI" is accepted. The significance value of SN is also the same so this hypothesis H3: "SN has positive Impact on GPI is also accepted. The hypothesis H4 is rejected because according to statistical analysis there is no impact of PBC on GPI. The impact of sub variables on the other variables the null hypotheses H6, H9, H10, H11, H12, H13, H14, H17, h19 are accepted and the hypotheses H5 H7, H8, $\mathrm{H} 15, \mathrm{H} 16, \mathrm{H} 18$ fits the criteria of being rejected as they were failed to find any impact on the other variable.

\section{Conclusion and Findings}

By applying the correlation and regression analysis we came to know the result of our key questions also known as research objectives that all the dependent and independent variables used in this study are positively correlated with each and the relationship is slightly strong. According to the finding of this study the impact of attitude on green purchase intention and green purchase behavior is positive which denotes that if the attitude is positive towards green consumption the intention and behavior will also be positive. Moving on to the impact of sub IVs on dependent variables, the sub independent variables like 
MNO, PAS, PEC, collectivism, LTO has positive impact on some variables and on some variables it has negative impact, while PAS was failed to find any impact on Attitude which means people in Pakistan do not think the government of Pakistan has done anything for green consumption promote green consumption practices.

\section{Future Recommendation}

The future researchers can use more variables like green awareness, consumer skepticism, green marketing. The future researchers can also use different theories related to human behavior according to the nature of their variables. This study was limited to the area of South Punjab; in the future more studies can be conducted on national and even international level. In this study we assumed the student as the only actual consumers, so if in the future if the researchers use the general public as population the result will be different and more close to reality. The researchers in the future could narrow down the topic of sustainability like green printers, green energy, recycling, reduction of plastic use as this issue is gaining a lot of attention these days and people are worried about the fact that plastic is non degradable synthetic material which is increasing day by day, and green clothing etc. Apart from the general public, further studies can be conducted in different sectors just like hospitals since the hospitals produce waste and dirty material, food sector, clothing etc. Different sampling methods can be used in the future research which can represent the whole population adequately. The enhanced sample size could be used for better outcomes. Last but not least, we used the span of 6 months, whereas in the future a longer time span can be used.

\section{Limitations of the study}

In this research we have several following limitations:

- The use of college and university students in the sample which limits our understanding of the customer mindset regarding this phenomenon.

- We have considered green consumption in general instead of narrowing it down to the specifics for if that had been the case; the findings would have been different for different products.

- The sampling method of random sampling method can also be considered a possible limitation because the respondent we are choosing on random basis may not be reliable. So in future other sampling methods should be chosen which can represent the whole population.

- Due to time limitation we conducted this study only in South Punjab. Future studies can extend the area of analysis on the national level and can also extend the context of the research among various sectors of the country.

\section{References}

Abdul-Muhmin, A. G. (2007). Explaining consumers' willingness to be environmentally friendly. International Journal of Consumer Studies, 31(3), 237-247. https://doi.org/10.1111/j.14706431.2006.00528.

Ajzen, I., \& Madden, T. J. (1986). Prediction of goal-directed behavior: Attitudes, intentions, and perceived behavioral control. Journal of Experimental Social Psychology, 22(5), 453-474. https://doi.org/10.1016/0022-1031(86)90045-4

Ali, A. (2016). Determinants of Pakistani Consumers ' Green Purchase Behavior : Some Insights from a Developing Country Determinants of Pakistani Consumers ' Green Purchase Behavior : Some Insights from a Developing Country, (April).

Ali, A., Khan, A. A., Ahmed, I., \& Shahzad, W. (2011). Determinants of Pakistani consumers' green purchase behavior: Some insights from a developing country. International Journal of Business and Social Science, 2(3), 217-226.

Am M A D Ri Z Wa N, M., Mm A D Ha Ssa N, M., Wa N Qa I Ser Dan I Sh, R. Z., \& Ri, I. (2017). Pakistan Journal of Life and Social Sciences Consumer's Characteristics and Social Influence Factors on Green Purchasing Intentions. Pak. j. Life Soc. Sci, 15(x), 2221-7630. Retrieved from www.pjlss.edu.pk

Aman, A. H. L., Harun, A., Hussein, Z., \& Author, C. (2012). The Influence of Environmental 
Knowledge and Concern on Green Purchase Intention the Role of Attitude as a Mediating Variable. British Journal of Arts and Social Sciences, 7(II), 2046-9578. Retrieved from http://www.bjournal.co.uk/BJASS.aspx

Arli, D., Tan, L. P., Tjiptono, F., \& Yang, L. (2018). Exploring consumers' purchase intention towards green products in an emerging market: The role of consumers' perceived readiness. International Journal of Consumer Studies, 42(4), 389-401. https://doi.org/10.1111/ijcs.12432

Aswal, K. (2017). Green Purchase Intentions, Collectivism and Materialism: An Empirical Investigation KAVITA SHARMA 1, (October), 39-56. https://doi.org/10.13140/RG.2.2.26270.18244

Autio, M., \& Heinonen, V. (2004). To Consume or Not to Consume? Young, 12(2), 137-153. https://doi.org/10.1177/1103308804042104

Bamberg Sebastian. (2003). How does environmental concern influence specific environmentally related behaviors? A new answer to an old question. Journal of Environmental Psychology, 23(1), 21-32.

Barber, N. A., Bishop, M., \& Gruen, T. (2014). Who pays more (or less) for pro-environmental consumer goods? Using the auction method to assess actual willingness-to-pay. Journal of Environmental Psychology, 40, 218-227. https://doi.org/10.1016/j.jenvp.2014.06.010

Brown, M., Pope, N., \& Voges, K. (2003). Buying or browsing? European Journal of Marketing, 37(11/12), 1666-1684. https://doi.org/10.1108/03090560310495401

Chan, R., \& Chan, R. Y. K. (2017). Determinants of Chinese Consumers' Green Purchase Determinants of Chinese Consumers ' Green Purchase Behavior, 18(August), 389-413. https://doi.org/10.1002/mar.1013

Cornelissen, G., Pandelaere, M., Warlop, L., \& Dewitte, S. (2008). Positive cueing: Promoting sustainable consumer behavior by cueing common environmental behaviors as environmental. International Journal of Research in Marketing, 25(1), 46-55. https://doi.org/10.1016/j.ijresmar.2007.06.002

Chaudhary, R., \& Bisai, S. (2018). Factors influencing green purchase behavior of millennials in India. Management of Environmental Quality: An International Journal, 29(5), 798-812. https://doi.org/10.1108/MEQ-02-2018-0023

Cherian, J., \& Jacob, J. (2012). Green marketing: A study of consumers' attitude towards environment friendly products. Asian Social Science, 8(12), 117-126. https://doi.org/10.5539/ass.v8n12p117

Concern, P. (n.d.). Sustainable Consumption : Issues and Challenges 1, 0-20.

Defranc, A., Van Den Broucke, S., Leroy, R., Hoppenbrouwers, K., Lesaffre, E., Martens, L., ... Declerck, D. (2008). Measuring oral health behaviour in Flemish health care workers: An application of the theory of planned behaviour. Community Dental Health, 25(2), 107-114. https://doi.org/10.1922/CDH_2120VandenBroucke08

Fien, J., Neil, C., \& Bentley, M. (2008). Youth Can Lead the Way to Sustainable Consumption. Journal of $\begin{array}{lllll}\text { Education } & \text { for } & \text { Sustainable } & \text { Development, }\end{array}$ https://doi.org/10.1177/097340820800200111

Gangwal, N., \& Bansal, V. (2016). Application of Decomposed Theory of Planned Behavior for Mcommerce Adoption in India, (May), 357-367. https://doi.org/10.5220/0005627503570367

Haanpää, L. (2007). Consumers' green commitment: Indication of a postmodern lifestyle? International Journal of Consumer Studies, 31(5), 478-486. https://doi.org/10.1111/j.1470-6431.2007.00598.x

Huang, Y. C., Yang, M., \& Wang, Y. C. (2014). Effects of green brand on green purchase intention. Marketing Intelligence and Planning, 32(3), 250-268. https://doi.org/10.1108/MIP-10-2012-0105

Iqbal, J. (2019). Current Scenario of Solid Waste in Pakistan - Technology Times. Retrieved May 10, 2019, from https://www.technologytimes.pk/current-solid-waste-pakistan/

Jay, M. (1994). Qt49N325B7.

Kluckhohn, F. R., \& Strodtbeck, F. L. (1961). Variations in value orientations. - PsycNET. Retrieved May 12, 2019, from https://psycnet.apa.org/record/1962-00928-000

Kumar, B. (2012). 10260621182012-12-08.

Leonidou, L. C., Leonidou, C. N., \& Kvasova, O. (2010). Antecedents and outcomes of consumer environmentally friendly attitudes and behaviour. Journal of Marketing Management, 26(13-14), 1319-1344. https://doi.org/10.1080/0267257X.2010.523710

Liobikiene, G., Mandravickaite, J., \& Bernatoniene, J. (2016). Theory of planned behavior approach to 
understand the green purchasing behavior in the EU: A cross-cultural study. Ecological Economics, 125, 38-46. https://doi.org/10.1016/j.ecolecon.2016.02.008

McCarty, J. A., \& Shrum, L. J. (2003). The Influence of Individualism, Collectivism, and Locus of Control on Environmental Beliefs and Behavior. Journal of Public Policy \& Marketing, 20(1), 93104. https://doi.org/10.1509/jppm.20.1.93.17291

Memar, N., \& Ahmed, S. ayub. (2012). Determinants which Influence the Consumers' Green Purchasing Intention, (June).

Moser, A. K. (2015). Thinking green, buying green? Drivers of pro - Environmental purchasing behavior. Journal of Consumer Marketing, 32(3), 167-175. https://doi.org/10.1108/JCM-10-2014-1179

Mufidah, I., Jiang, B. C., Lin, S. C., Chin, J., Rachmaniati, Y. P., \& Persada, S. F. (2018). Understanding the consumers' behavior intention in using green ecolabel product through Pro-Environmental Planned Behavior model in developing and developed regions: Lessons learned from Taiwan and Indonesia. Sustainability (Switzerland), 10(5), 1-15. https://doi.org/10.3390/su10051423

Nam, C., Dong, H., \& Lee, Y. A. (2017). Factors influencing consumers' purchase intention of green sportswear. Fashion and Textiles, 4(1). https://doi.org/10.1186/s40691-017-0091-3

Nguyen, T. N., Lobo, A., \& Greenland, S. (2017). Marketing Intelligence \&amp; Planning The influence of cultural values on green purchase behaviour The influence of cultural values on green purchase behaviour. Marketing Intelligence \& Planning Food Journal Iss Environmental Quality: An International Journal, 35(4), 377-396. https://doi.org/10.1108/

Patil, S., \& Patil, M. (n.d.). Articles Junction: Green Consumption Definition, Green Consumption Importance. Retrieved April 5, 2019, from http://articles-junction.blogspot.com/2013/07/greenconsumption-definition-green.html

Paul, J., Modi, A., \& Patel, J. (2016). Predicting green product consumption using theory of planned behavior and reasoned action. Journal of Retailing and Consumer Services, 29, 123-134. https://doi.org/10.1016/j.jretconser.2015.11.006

Pollard, M., Kalafatis, S. P., Tsogas, M. H., \& East, R. (1999). Green marketing and Ajzen's theory of planned behaviour: a cross-market examination. Journal of Consumer Marketing (Vol. 16). https://doi.org/10.1108/07363769910289550

Promotosh, B. (2011). Barua Promotosh (2011).pdf.

Ramayah, T., Lee, J. W. C., \& Mohamad, O. (2010). Green product purchase intention: Some insights from a developing country. Resources, Conservation and Recycling, 54(12), 1419-1427. https://doi.org/10.1016/j.resconrec.2010.06.007

Rizwan, M., Asif, R. M., Hussain, S., Asghar, M., Hassan, M., \& Javeed, U. (2013). Future of Green Products in Pakistan: An Empirical Study about Green Purchase Intentions. Asian Journal of Empirical Research, 3(2), 191-207. Retrieved from http://www.aessweb.com/download.php?id=1815

Shaikh, A. S. (2019). Consumer Perceptions of Green Products: A Survey of Karachi. Journal of Independent Studies and Research-Management, Social Sciences and Economics, 9(2), 15-29. https://doi.org/10.31384/jisrmsse/2011.09.2.2

Sharma, P. (2010). Measuring personal cultural orientations: Scale development and validation. Journal of the Academy of Marketing Science, 38(6), 787-806. https://doi.org/10.1007/s11747-009-0184-7

Sreen, N., Purbey, S., \& Sadarangani, P. (2018). Impact of culture, behavior and gender on green purchase intention. Journal of Retailing and Consumer Services, 41(December 2017), 177-189. https://doi.org/10.1016/j.jretconser.2017.12.002

Tommasetti, A., Singer, P., Troisi, O., \& Maione, G. (2018). Extended Theory of Planned Behavior (ETPB): Investigating customers' perception of restaurants' sustainability by testing a structural equation model. Sustainability (Switzerland), 10(7), 1-21. https://doi.org/10.3390/su10072580

Vantamay, N. (2018). Kasetsart Journal of Social Sciences Investigation and recommendations on the promotion of sustainable consumption behavior among young consumers in Thailand, 1-8. https://doi.org/10.1016/j.kjss.2018.01.007

Wijaya, T. (2017). Nilai orientasi alami manusia dan pengetahuan organik sebagai determinan perilaku beli pangan organik. Jurnal Siasat Bisnis, 21(2), 161-180. 
https://doi.org/10.20885/jsb.vol21.iss2.art5

Yadav, R., \& Pathak, G. S. (2017). Determinants of Consumers' Green Purchase Behavior in a Developing Nation: Applying and Extending the Theory of Planned Behavior. Ecological Economics, 134, 114-122. https://doi.org/10.1016/j.ecolecon.2016.12.019

Zia-ur-Rehman, \& Dost, M. K. Bin. (2013). Conceptualizing Green Purchase Intention in Emerging Markets : An Empirical Analysis on Pakistan. WEI International Academic Conference Proceedings, 99-120. https://doi.org/10.1016/j.arbres.2011.10.008 